\title{
Energetic tourism: exploring the experience quality of renewable energies as a new sustainable tourism market
}

\author{
A. Jiricka, B. Salak, R. Eder, A. Arnberger \& U. Pröbstl \\ Institute of Landscape Development, Recreation and Conservation \\ Planning, University of Natural Resources and Applied Life Sciences, \\ Austria
}

\begin{abstract}
To tackle the global problem of climate change, it will be crucial that the global economic system adopts energy-saving measures and furthers its reliance on renewable energy sources. This challenge is particularly relevant for the tourism industry, which depends on transportation by definition, and is highly dependent on resources and energy in many other regards. Tourism can quickly be caught in a vicious cycle: the necessity to adapt to climate change, i.e. by increasing artificial snow making, or new product development as exemplified by the "wellness-boom", leads to ever higher rates of energy consumption, thus further contributing to climate change. However, the fledgling human explorations towards combating climate change and increasing energy efficiency also offer innovative opportunities for exploring new niches of tourism.

This paper presents how such novel tourism opportunities avail themselves around the theme of renewable and sustainable energy use. Combining environmental education and experiencing novel products can be used for marketing a fundamentally new tourism product, which attracts both the technologically interested tourism segment and the family-oriented traveler. This may lead to positive perception of climate change adaptation strategies.

A summary of "model" energy regions in Central Europe describes the typical characteristics that regions must have for possibly developing these innovative tourism niches. The main focus of the paper is on "eco-energy region" of Guessing, Burgenland, which is involved in an on-going transnational research project -for sustainable tourism development in Central Europe (Interreg IVB). The area around Austria's only energy self sufficient city
\end{abstract}


(Güssing) is situated in a nature park at the eastern foothills of the Alps. Due to the mild climate this region is a part of the so called "Austrian Tuscany". Multicultural influences by the proximity to Hungary, Slovenia and Slovakia are reflected by various cultural, especially culinary experiences. Due to its location along the former iron curtain, the region has remained fairly remote and is not recognized as a tourism destination. However, with the eco-energy project of Guessing gaining world-wide recognition, it became obvious that in addition to the business and conference driven energy tourism, an opportunity for a leisure oriented tourism development also availed itself. This paper presents the innovative strategies that the region will focus on in order to expand to a more complete and sustainable energy-tourism destination.

Keywords: experience-oriented tourism, niche tourism, tourism product, energytourism, tourism marketing, tourism demand, rural tourism, tourism development, area in transition, renewable energy.

\section{Introduction}

The new millennium will become the period of a transition to a more sustainable economic system based on renewable energies. The trend towards energy autonomy has been supported in the last decade by increasing global political instabilities, and higher prices for natural resources and energy. Furthermore the moral aspect associated with discussions around climate change puts pressure on consumer industries especially if they are energy intensive, as their clients are becoming increasingly critical about excessive energy consumption and tourism is one of them. Recent studies claim that tourism is one of the most important contributors to global warming, accounting for approximately $9 \%$ of the global greenhouse gas emissions [10]. For example, media campaigns on climate change have occasionally targeted winter tourism with its energy intensive mitigation strategy of snow making. The trend to wellness tourism and summer tourism in general also has been targets of the debate. Several initiatives have been started in the last years to promote renewable energies in tourism industries ([14], e.g. www.renewabletourism.com)

Michalena [14] points out that especially those destinations which are particularly vulnerable to climate change (e.g. islands) make greater efforts in introducing renewable energy sources. Especially in the Mediterranean area solar energy, wind and tidal power can account for a huge amount of the energy consumption by the tourism industry. Similar trends can be observed in alpine ski areas, as leading destinations start to shift to energy self-sufficiency [20].

In this context knowledge transfer has become an important business factor. The visitor programs and exhibits of technology parks and centers play a crucial role in the knowledge transfer to the interested public - mainly city councils and policy makers and the specialized private sector [22]. These centers offer guided tours to view the technical facilities, and give presentations about their specific approaches and possible solutions. In Austria and South Tyrol many visitors are attracted to this new kind of business tourism. 
A rather new approach tries to extend the interest on renewable energies from business tourism only to certain segments of the general public. Whereas the specialized public tends to stay only short time, leisure time visitors and tourists could be enticed to stay longer and thus contribute significantly to the regional economy.

This may also meet the political strategies to reduce climate warming by private application of renewable energies and knowledge about energy savings.

This paper examines the first attempts towards this goal of expanding this niche of "energy-tourism", both for the specialized public (in the following called the "expert-oriented tourism") and the vacationers (in the following called the "experience-oriented tourism"). The investigation reveals its potential as new niche tourism segment in regions with little (or no) previous tourism development and shows possible exhibits and activities within a best practice approach for combining the two previously mentioned options of energy-based tourism.

One goal of the Interreg Central Europe project "Listen to the voice of villages" (www.listentothevoiceofvillages.org) is to develop a new management tool for promoting sustainable tourism for areas in transition. Its emphasis ought to be on niche tourism products. Each region follows a different approach regarding its tourism product.

However, the over-arching theme is sustainability. The project allows for comparing different niche-tourism strategies and to find key-criteria for the successful implementation and/or enhancement of the tourism infrastructure. The Austrian case study around Güssing will focus on the topic of energy related tourism. First results of this project will be presented below.

\section{Methodological approach and theoretical framework}

In the first step of our research we analyzed regions which already promote themselves as "energy-regions". No general definition for an energy-region exists. We included all those regions, which try to practice "innovative and sustainable solutions for sustainable energy supply and efficiency"[11], and the analysis will focus on scale, organizational structures and goals, as well as the impact on the local identity and the overall marketing. In our study we concentrated on energy-regions in Central Europe, mainly the German speaking area (Austria, Germany, Switzerland and the Northern part of Italy).

In the second step we applied the framework of the tourism strategy for Austria 2015. It provided the basis to evaluate positive impacts on tourism [21]. The framework for the tourism enhancement in Austria developed by the Austrian Institute for economic research is based on four elements:

- the quality, diversity and structure of the integrated and supporting branches and institutions

- framing conditions such as working conditions for employees, structure of the product, productivity and others 
- the market chain, its organizational structure and the booking opportunities

- conditions of demand.

These four elements are mainly influencing the competitiveness of Austria as a tourism destination. They might be influenced by tourism policy and eventually by tourism specific impacts ("shocks"). See figure 1.

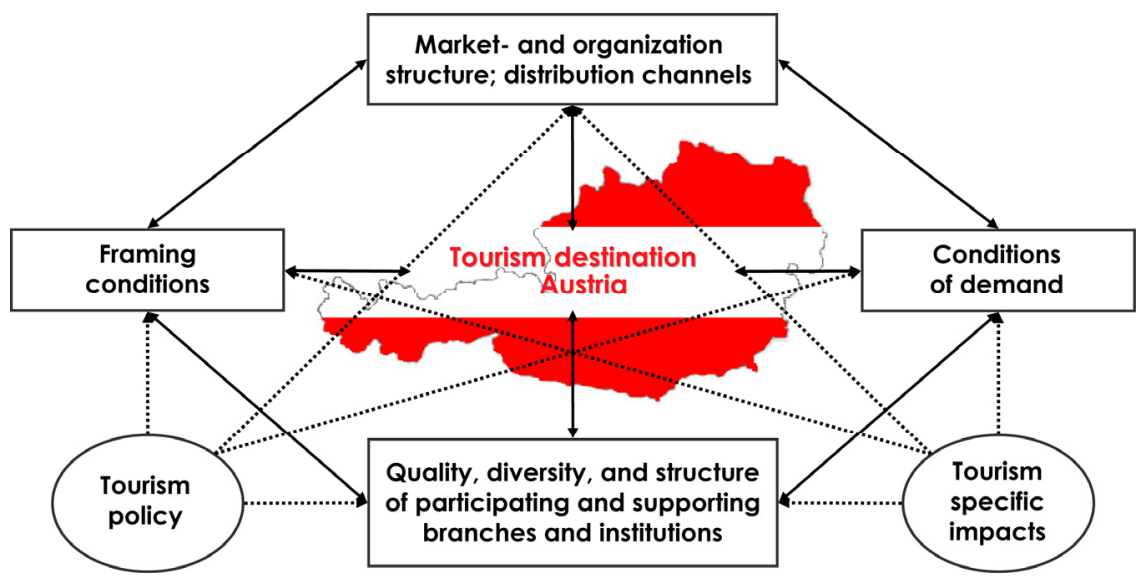

Figure 1: Impact on tourism according to the Austrian tourism strategy 2015 (source: translated adaptation from Smeral 2005).

Using this framework we will discuss the opportunities and required measures to implement the new niche product "energy-tourism". In contrast to mass tourism, niche tourism aims at establishing a different tourism operator-customer relationship. Niche-tourism clients are defined as being more aware of their role and influence as consumers in the world. They perceive sustainable tourism products as a meaningful set of activities. Both the body and the brain should profit from the vacation. A further very important component is the emotional experience [18], which fits to the individual and more intimate experience they wish to have.

Trend related research in Central Europe shows a shift from consumption and luxury oriented tourism to an experience orientation. Successful tourism offers significant and unique experiences instead of fulfilling needs [15, 17, 19]. Therefore we included this aspect in the evaluation of existing products. The main hypothesis is that energy regions can build their product on two different pillars:

1. Professional visitors, who visit to gain new knowledge for their communities, their enterprises, or their business.

Target groups for this "expert-oriented energy tourism" are community leaders, enterprises, universities and technical schools. The existence of 
renewable energy plants and the implementation of sustainable energy concepts in the region are the pre-conditions for this tourism. Technical innovation, transfer of know-how and the possible adaptability for the own region are the key motives for the visit. The visit is part of the professional life and not a holiday trip. The knowledge transfer aims at the cognitive dimension; technological facts, costs and benefits are discussed during guided tours or seminars. Expert-oriented tourism mainly works on a day-trip based concept, focusing on workdays. The option to extend the professional visit to discover the culinary, cultural or natural tourism offers in the region certainly exists.

2. New fun oriented infrastructure using the same technology could attract an additional segment, especially families and groups of children.

This "experience-oriented energy tourism" is leisure-oriented. It builds on the basis of the know-how, infrastructure, marketing and branding of the energy region. Experience oriented energy tourism intends to create infrastructure and attractions as a "stand-alone" offer, or as programs combined with "traditional tourism offers", so that visitors are enticed to stay for several days. Target groups are families, as well as the group of "LOHAS" (Lifestyle of Health and Sustainability) that implies environmental-conscious and in most cases welleducated individuals. The main motive for visiting is recreation. Renewable energy plants with emotive communication tools or other energy based educational infrastructure such as an energy fun park, energy trails or energy exhibitions can be important incentives to choose this particular region for holidays.

One pre-condition for the educational infrastructure to work within the leisure-vacation context is that it ought to have a fun-oriented conception. In comparison with the expert-oriented tourism the integration of an affective and kinesthetic dimension is very important. First hand experiences and learning by doing are the most important communication tools. The relevance of renewable energies and their functionality should be discovered through self-exploring. Everybody should recognize the importance of the use of renewable energy for sustainable development. Family-oriented offers and holiday camps are important parts for this experience-oriented tourism. The duration of stay ranges from a one-day trip to several weeks.

Usually, school groups do not fit into this second group as they visit during their "work time" and the trip is organized by a teacher. There is no doubt however that the communication targeting the non-experts follows the rules of the experience-oriented tourism [8]. A fascinating school excursion in an energyregion can be a crucial factor that students will return with their parents.

This possible new concept for energy tourism which will be discussed against the case study and other examples is presented in figure 2 . 


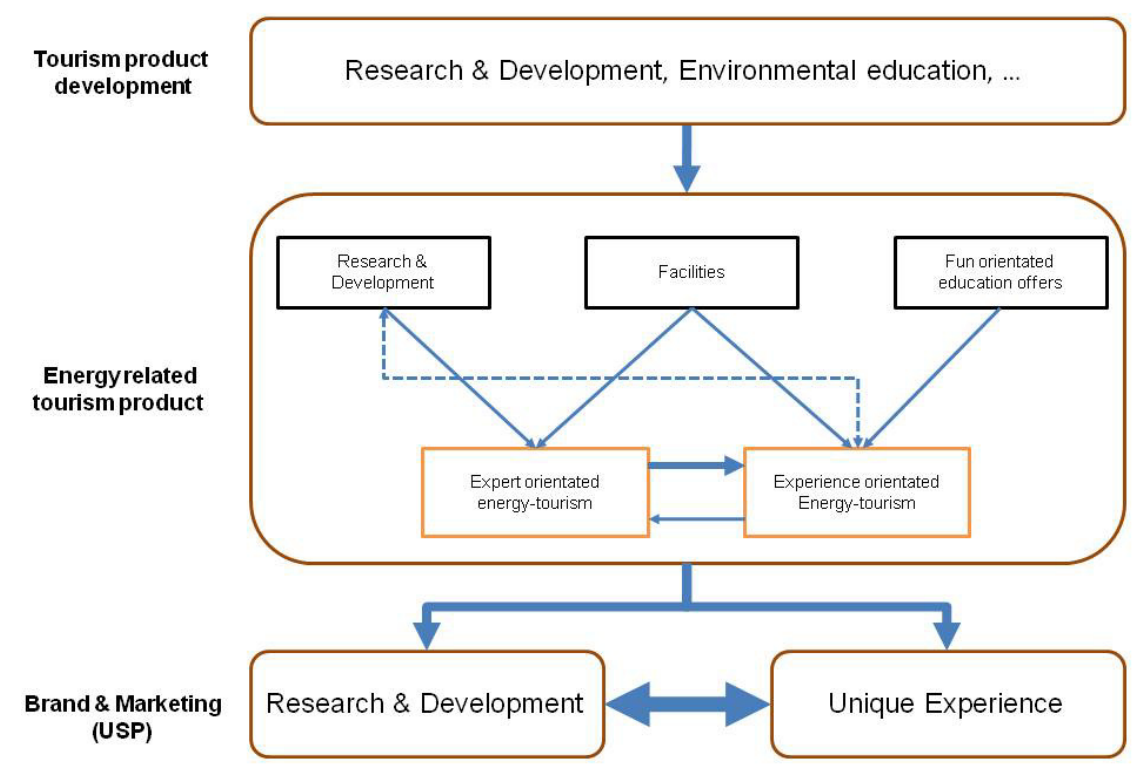

Figure 2: Development of energy-related tourism as a new niche tourism product.

\section{Results}

\subsection{Analysis of "energy-regions"}

In the following we present the analysis of all regions which promote themselves as energy-regions. The term the regions use to promote themselves differ slightly while essentially referring to the same concept: "eco-energy region" (Güssing, AUT), "energy-region” (Weiz-Gleisdorf AUT), "energy-landscape” (Morbach, GER), "bio-energy-village” (Jühnde, GER), "energy-vision” (Murau, AUT), "energy-valley" (Toggenburg, CH), "energy-change" (Oberland, GER). All these are regions, landscapes or villages which want to implement renewable energy projects. In this publication, these different terms are summed up under the term "energy-region".

The scale ranges from a single rural municipality (e.g. Jühnde, Barlissen in Germany, or Sand in Taufers in Italy) to regional cooperation in urban or suburban areas driven by regional development institutions, e.g. in Güssing, Murau, Weiz-Gleisdorf, Salzkammergut (all Austria), Goms (CH), Nürnberg, Freiburg (GER). One should also note that several national or provincial/state governments (e.g. Burgenland in Austria or South Tyrol in Italy) define the emphasis on renewable energies explicitly in their development strategies. For 
the purpose of defining niche tourism in the context of this paper we refer, to tourism units at the regional and local level only.

The organizational structures of these energy-regions differ significantly. Private associations, cooperatives, regional management associations, tourism associations, municipalities, local entrepreneurs and/or private participants are the most common steering structures.

In many cases it is a higher level administrative decision to initiate an energy region, but in the end if the concept is to be successful, there must be a bottomup support for its successful implementation. Therefore it is essential to raise awareness among the population; in several examined regions this aspect is still largely absent.

\subsubsection{Targets and effects on the local economy}

For many of the energy-regions analyzed, autarky is the major goal for implementing the new technologies. Autarky is not only a way to provide independence but also to reduce the atmospheric $\mathrm{CO}_{2}$ level and to keep expenditures in the region. Typical goal definitions are "By 2020 the region produces the same amount of energy as is consumed" [5], or somewhat vaguer such as "positioning (...) as the "European model region for Renewable Energy and Energy Efficiency” (...)"[4].

Most of the renewable energy projects are launched in rural areas, where investments help the local economy to get more dynamic: "Renewable energy is not only good for our economic security and the environment, it creates new jobs" [9]. Therefore, younger people will perceive new economic opportunities and are more likely to stay, which will strengthen the local identity. In other words, such a renewable energy project can contribute to economic diversification and stabilize a peripheral economy [7].

Finally, the marketing of special know-how is a key issue in those energy regions, which established institutions for technological research and knowledge exchange. They attract visitors who want to learn more about the state of the art in sustainable energy technologies, participate on guided tours and evaluate what is interesting for their own region. This concept is the basic structure for expert orientated-/knowledge tourism. In these areas increasing visitor numbers are observed. In South Tyrol (ITA) about 3,000 to 4,000 visitors per year were registered in 2006 [3]. In Güssing (AUT) around 21,000 visitors per year [13] were counted. Many regions (e.g. Güssing (AUT), Jühnde (GER)) created a modular booking system where visitors can book several types of excursions (field trips, special- and individual excursions) via the web and in advance. In most cases the activities are coordinated by a "centre for renewable energies" (e.g. Center for New Energies/Jühnde (GER), Renewable Energy Center, Renertec/Bozen (ITA), European Centre for Renewable Energy/Güssing (AUT)).

Closer scrutiny of the specific products in the various regions shows a rather diverse suite of activities, needed for the different target groups. Following the strategic framework from [21] and the main Austrian tourism policy concept the different requirements are summarized in table 1. 
Table 1: Characterization of expert-oriented and experienced-oriented energy tourism - first suggestion.

\begin{tabular}{|c|c|c|c|}
\hline $\begin{array}{l}\text { Determining } \\
\text { reasons for the } \\
\text { competitiveness } \\
\text { of a tourism } \\
\text { destination }\end{array}$ & $\begin{array}{l}\text { Sub } \\
\text { dimension }\end{array}$ & $\begin{array}{l}\text { Expert-oriented energy } \\
\text { tourism }\end{array}$ & $\begin{array}{l}\text { Experienced-oriented } \\
\text { energy tourism }\end{array}$ \\
\hline \multirow{9}{*}{ Demand } & Target group & $\begin{array}{l}\text { Communities (mayors, } \\
\text { relevant stakeholders, } \\
\text { regional managers), } \\
\text { enterprises, universities, } \\
\text { (school groups) }\end{array}$ & $\begin{array}{l}\text { Individual tourists } \\
\text { especially families, kids } \\
\text { and youth groups }\end{array}$ \\
\hline & \multirow{3}{*}{ Motive } & Work & Leisure \\
\hline & & $\begin{array}{l}\text { Information, (further) } \\
\text { Education }\end{array}$ & $\begin{array}{l}\text { Recreation and informal } \\
\text { education (edutainment) }\end{array}$ \\
\hline & & $\begin{array}{l}\text { factual and practical } \\
\text { knowledge }\end{array}$ & practical knowledge \\
\hline & Group size & Mostly larger groups & $\begin{array}{l}\text { Wide spectrum from small } \\
\text { groups (families) to large } \\
\text { groups (youth camps) }\end{array}$ \\
\hline & Duration of stay & Short stay (1-2 days) & $\begin{array}{l}\text { Short stay (weekend trips) } \\
\text { or longer stay (combination } \\
\text { with other tourism offers, } \\
\text { camps) }\end{array}$ \\
\hline & $\begin{array}{l}\text { Temporal } \\
\text { patterns }\end{array}$ & $\begin{array}{l}\text { Workdays } \\
\text { Independent from weather } \\
\text { conditions }\end{array}$ & $\begin{array}{l}\text { Weekend, holidays } \\
\text { Depends on weather } \\
\text { conditions (seasonal) }\end{array}$ \\
\hline & \multirow[t]{2}{*}{ Spatial patterns } & $\begin{array}{l}\text { Use of energy sites only } \\
\text { (from energy site to energy } \\
\text { site) }\end{array}$ & $\begin{array}{l}\text { Use of complete tourism } \\
\text { infrastructure and several } \\
\text { energy sites }\end{array}$ \\
\hline & & $\begin{array}{l}\text { Indoor (and outdoor around } \\
\text { energy facilities) }\end{array}$ & Outdoor and indoor \\
\hline \multirow{3}{*}{$\begin{array}{l}\text { Quality, diversity } \\
\text { and structure of } \\
\text { the involved } \\
\text { Branches and } \\
\text { Institutions }\end{array}$} & $\begin{array}{l}\text { Type of } \\
\text { accommodation }\end{array}$ & Hotels, seminar hotels, & $\begin{array}{l}\text { Hotels, bed and breakfast, } \\
\text { guesthouse, farms, } \\
\text { campgrounds, special } \\
\text { camps }\end{array}$ \\
\hline & $\begin{array}{l}\text { Quality of } \\
\text { accommodation }\end{array}$ & $\begin{array}{l}\text { raised (business) standard } \\
\text { (accommodations close to } \\
\text { the renewable plants) }\end{array}$ & All categories \\
\hline & $\begin{array}{l}\text { Connection to } \\
\text { other tourism } \\
\text { offers }\end{array}$ & $\begin{array}{l}\text { Culinary (wine tasting, } \\
\text { regional specialties) or } \\
\text { cultural offers possible as } \\
\text { additional incentive }\end{array}$ & $\begin{array}{l}\text { Offer of attractive tourism } \\
\text { infrastructure and } \\
\text { packages to keep the } \\
\text { visitor in the region }\end{array}$ \\
\hline \multirow[t]{2}{*}{ Framing conditions } & $\begin{array}{l}\text { Communication } \\
\text { concept }\end{array}$ & $\begin{array}{l}\text { Focus on cognitive } \\
\text { dimension (rational mind) }\end{array}$ & $\begin{array}{l}\text { Focus on affective } \\
\text { (feelings) and kinesthetic } \\
\text { (motor skills) dimensions } \\
\text { "learning by doing and } \\
\text { feeling", first hand } \\
\text { experience }\end{array}$ \\
\hline & $\begin{array}{l}\text { Type of } \\
\text { information }\end{array}$ & $\begin{array}{l}\text { (technological) facts about } \\
\text { costs, benefits, } \\
\text { adaptability, } \\
\text { factual and practical } \\
\text { knowledge }\end{array}$ & $\begin{array}{l}\text { Exploring the functionality } \\
\text { und relevance of } \\
\text { renewable energies in a } \\
\text { playful way } \\
\text { practical knowledge }\end{array}$ \\
\hline
\end{tabular}


Table 1: $\quad$ Continued.

\begin{tabular}{|c|c|c|c|}
\hline $\begin{array}{l}\text { Determining } \\
\text { reasons for the } \\
\text { competitiveness } \\
\text { of a tourism } \\
\text { destination }\end{array}$ & $\begin{array}{l}\text { Sub } \\
\text { dimension }\end{array}$ & $\begin{array}{l}\text { Expert-oriented energy } \\
\text { tourism }\end{array}$ & $\begin{array}{l}\text { Experienced-oriented } \\
\text { energy tourism }\end{array}$ \\
\hline \multirow[t]{3}{*}{ Framing conditions } & $\begin{array}{l}\text { Communication } \\
\text { tools }\end{array}$ & $\begin{array}{l}\text { Guided tours, expert } \\
\text { lectures, discussions } \\
\text { seminars }\end{array}$ & $\begin{array}{l}\text { Guided offers, self } \\
\text { discovery offers (e.g. } \\
\text { interpretive energy trail, } \\
\text { energy fun park, } \\
\text { exhibitions, brochure) } \\
\text { coached offers like holiday } \\
\text { camps }\end{array}$ \\
\hline & $\begin{array}{l}\text { Customer } \\
\text { support }\end{array}$ & Guided offers & $\begin{array}{l}\text { Self guided or guided } \\
\text { offers }\end{array}$ \\
\hline & $\begin{array}{l}\text { Quality of } \\
\text { experience }\end{array}$ & $\begin{array}{l}\text { Focus on information } \\
\text { quality }\end{array}$ & $\begin{array}{l}\text { Focus on service quality } \\
\text { and tourism specific } \\
\text { experience }\end{array}$ \\
\hline \multirow[t]{2}{*}{$\begin{array}{l}\text { Marketing, } \\
\text { Organizational } \\
\text { structure, Booking }\end{array}$} & $\begin{array}{l}\text { Communication } \\
\text { tools }\end{array}$ & $\begin{array}{l}\text { Energy market specific: } \\
\text { scientific and popular } \\
\text { scientific journals, } \\
\text { conferences or seminars, } \\
\text { community networking }\end{array}$ & Tourism-website, folder \\
\hline & \begin{tabular}{|l|} 
Communication \\
concepts
\end{tabular} & $\begin{array}{l}\text { Focus on renewable } \\
\text { plants, know-how transfer }\end{array}$ & $\begin{array}{l}\text { Concepts related to the } \\
\text { region as a whole }\end{array}$ \\
\hline
\end{tabular}

\subsection{Case study}

\subsubsection{Description of the energy region Güssing (AUT)}

The study focuses on a region located in the Austrian province of Burgenland around the city of Güssing. Güssing is the capital of a district with about 27,000 inhabitants. Until the mid 1980s, this region ranked as one of the poorest in Austria, because of its location along the former iron curtain and the lack of industrial business and transportation infrastructure (e.g. railroad, highway). Few employment opportunities existed, resulting in a high rate of weekly commuters and migration to other regions. Energy (oil, fuels, electricity) was bought from outside, while a lot of existing resources like agricultural land ( $45 \%$ forests) remained unused [1].

In 1990, some "pioneers" recognized this potential and developed a model for a complete abandonment of fossil energy use for the region. The aim was to supply the city of Güssing with regional renewable energy sources and then, step by step, the whole region [2]. In 2001, Güssing was Austria's first energy selfsufficient city based on the construction of numerous energy plants and an energy optimization of all buildings in the town centre. The further plan is that in 2010 the whole district should be self-sufficient $[1,12]$.

This innovative energy concept resulted in a sustainable regional development process: more than 50 new enterprises were established creating more than 1,000 direct and indirect jobs in the renewable energy sector. Based 
on the construction of the biomass plant Güssing (flagship and most important innovation; it uses a special fluidized bed steam gasification technology) and the foundation of the Renewable Energy Network Austria, many international and national research projects were initiated in Güssing [12].

In 1996, the European Center for Renewable Energy (EEE) was founded to coordinate all demonstration plants, research projects and to develop seminars for further education. Today, more than 30 demonstration plants using different technologies (biomass, biogas, solar and photovoltaic installations) can be visited around Güssing. Currently about 600 to 1,000 people visit the plants in Güssing each week [23]. The city with technical infrastructure is now a "Mekka" for technological innovation. Most of the visitors are daily tourists, but the number of overnight stays is increasing (over-night-stays Güssing 1991: 27,000, in 2005: 250,000; [23]). The visitors come from Austria, all over Europe, USA, and Canada, as well as from Japan and China. A special attraction for many visitors is the above mentioned biomass plant. At the moment, the majority of visitors are "expert-oriented energy tourists" who spend only a short time in the region. Therefore in 2005, the EEE and 10 communities from the region established the "Öko Energieland-Eco Energy Land" (ÖEL) to create a label suitable for (leisure) tourism promotion [23].

Its main goals are to create tourism packages for the expert visitors to extend their visit into an over-night sojourn in the region, and to provide information about renewable energies for "normal" tourists. Initial steps involve the training of certified tourist guides to enable them to offer guided tours to the different demonstration plants, or the eco-energy marathon in cooperation with sport organizations [1]. A $125 \mathrm{~km}$ bicycle trail through the participating regions containing 12 objects with slight to strong relation to the topic of renewable energies has been installed. Different renewable energy plants can be visited along the trail.

\subsubsection{Analysis of the Austrian case study}

In the following the offers of the Austrian case study are examined according to the criteria of the Austrian tourism Strategy 2015, which was presented in chapter II.

\section{Conditions of demand}

At the moment the eco-energy Centre in Guesing attracts mainly professional visitors and "experts". At the moment, the region provides only few additional attractions for energy-related visitors. Offers which are currently available (such as the biking trail and other infrastructure) are not linked to the main theme: ecologically friendly energy from biomass or solar power. The additional offers are perceived mainly as an "occasional element" in the landscape and do not invite people to explore additional information. Visitors are not aware of benefits and the offers are not attractively communicated.

Attractions for the professional visitor would need to be integrated topically, and should serve as an added incentive for an extending their stay in the region. They will be accepted only if they become an integrated component of the main 
visitor programs. This was aimed at by the foundation of the "ÖkoenergielandEco energy land" but has not been efficiently realized at the moment.

For the weekend visitors or tourists the demand is not yet created. If people are currently visiting the area in their leisure time it is mostly a short time visit and the main motives are recreation in the nature parks nearby. Yet there would be a demand for further attractions, especially if they are linked to the overall topic of sustainable living and nature experience. Culinary and gastronomic services nearby could profit in the future from visitors. Actually the hotel infrastructure is mainly oriented to the needs of business visitors, who stay only a few days.

\section{Framing conditions (e.g. working conditions for employees, structure of the product, productivity)}

Although the presented product has a worldwide recognition and the presentations are of a high informative quality, the overall infrastructure and service quality needs to be improved. The quality can be improved easily to the high standards of international clients. One step in this direction would be the adaptation of the Güssing castle, in cooperation with the owner, as an attractive information centre. This new location of the information centre could be the prerequisite for new offers and attracting new target groups such as the experience oriented visitors, potentially extending their sojourn.

In order to increase the number of leisure visitors the infrastructure requires new experience oriented offers. At the moment only a few events invite visitors to participate actively - such as the energy guides for tourists and the eco-energy marathon. A more pedagogically oriented infrastructure such as energy-trails (educational signs, PDA), energy-parks or energy-camps which can attract families, kids and youth, is mostly lacking. Such offers will encourage visitors to explore the functionality of renewable energies and discover the relevance for their own life in a playful way. As people visit these offers in their leisure time, a fun oriented educational infrastructure is required (Edutainment).

\section{The quality, diversity and structure of the integrated and supporting branches and institutions}

The cooperation with other branches (e.g. food industry, technical industries etc.) could be enhanced to improve the conditions for the professional visitor and form the basis for additional target groups. For example, the regional strategies and networks within the tourism industry need to be improved, such as tasting of local wines and other traditional events. This is in particular important to attract more leisure tourists.

A new standard regarding the quality, the diversity and the structure of the integrated and supporting branches in Güssing is recommended. One very successful factor is the strong cooperation in science and innovation (e.g. in transnational projects). This made Güssing to one of the key-institutions in renewable energies and increased their high profile. 


\section{The market chain, its organizational structure and the booking opportunities}

Closer scrutiny of the final criteria, the market- and organizational structure shows that the technical offer in Güssing and its surrounding areas do not perceive themselves as one organizational structure. It is still difficult to book a technical presentation, a visit in the wine museum with wine tasting and a hotel stay as one product. The presentation and booking opportunities could be enhanced significantly. A close cooperation between the various enterprises, the tourism office and various locations in the region could be enhanced.

In this context also cross cultural marketing and new marketing strategies, which address the possible experience oriented customer are required. A combination of these various niche tourism types would have great potential in the international market.

In summary, the analysis shows that the business-related aspect of tourism is well established and integrated into international networks, but it can be expanded significantly by itself with increasing focus on improvements in service quality and the integration of additional tourism branches within the Guessing region and what is currently considered its immediately adjacent periphery.

On the other hand, the adaptation of energy topics for a much broader layperson type audience requires a special strategy independent from the wellestablished product of the expert-oriented tourism. There is the need for more inter-active offers with a strong emphasis on whole-family products and selfexperiencing fun activities.

\section{Outlook and conclusion}

This paper promotes the fledgling field of energy-tourism as a new niche-tourism segment. The challenge to turn energy consumption into a climate friendly process can be supported by these concepts. It contributes to the development and promotion of sustainable development but also the creation of jobs is a positive effect [6].

The typical characteristics of niche tourism according to common definitions [16] can be found in this new expanding offer:

Energy-tourism fulfils the criteria of being sustainable in two ways. First the tourism experience itself can be organized in a sustainable way (e.g. trough "solar camps" using solar mobility as well as energy for camp housing and activities), and second it has a long-term sustainability if it is successful in attracting more people to integrate renewable energy sources in their lives.

Furthermore, it is an economically and socially sustainable economic activity for the region as it allows combining a knowledge-driven economy, agriculture and tourism. Moreover, energy tourism can be combined with other tourism products. Instabilities in tourist demand can be stabilized more easily than by focusing only on one tourism product (e.g. wellness-tourism). It offers a knowledge-driven and meaningful holiday-experience. The experience component is the major target for the leisure-oriented tourism. 
While the expert-oriented type of tourism has been established over the last ten years, which is based on a clearly defined costumer profile, the experienceoriented tourism potential has not yet been realized. For the described new energy tourism a clear profile and product setting must be developed. Only then will the future tourist be able to recognize energy related offers as new tourism niche product. Currently visitors only find undefined offers which lack a holistic strategy. For experience oriented-tourism market research on tourist preferences is necessary.

The example of the eco-energy region of Güssing in Austria shows that niche tourism based on eco-energy has the potential to attract both the expert-orientedtourism and the experience oriented tourism. Strategies to establish and also to combine these two approaches could be a successful option for this area - from an economical and tourist point of view.

The expert-oriented tourism focuses particularly on the transfer of technical know-how. An "in-depth" emotional experience - which is one of the core criteria of niche tourism - can only be created when both the brain and the body are addressed. In cooperation with local enterprises we aim to develop infrastructure with an "explorative" component, which aims at discovering creative applications and "new terrains". This leads to a holistic holiday experience. If the knowledge gained can be transferred to the daily lives an additional benefit is obtained. The development of this new tourist infrastructure should be supported by an evaluation of the visitor preferences and the successes of initializing offers.

Summarizing, the examination of the case study made the great potential for energy tourism evident. Güssing has exploited this potential for a well established expert oriented tourism. The challenge for the future is to develop sustainable experience oriented tourism packages for the whole region and market this under a common label.

\section{References}

[1] Austrian Federal Ministry for Transport, Innovation and Technology (bmvit). Model Region Güssing. Forschungsforum Nachhaltig Wirtschaften: Wien, 2007.

[2] Brunner, C., Hotwagner M., Kopitar, A., Güssing/Südburgenland - erste energieautarke Stadt Österreichs. Informationen zur Raumentwicklung, 1(2), pp. 93-101, 2006.

[3] Commission Internationale pour la Protection des Alpes (CIPRA). Energietourismus Südtirol, http://www.cipra.org/competition/Renertec/

EnergieRegion OststeierMark. Unsere Ziele. http://www.energieregionoststeiermark.at/index.php?option=com_conten $t \&$ task $=$ view\&id $=19 \&$ Itemid $=43$

[5] Energieregion Weiz-Gleisdorf. Zielsetzung: Unsere Vision. http://www.energieregion.at/index.php?id=17 
[6] European Commission. The impact of renewable energy policy on economic growth and employment in the European Union. Brussels, 2009.

[7] Federal Ministry for the Environment, Nature Conservation and Nuclear Safety. Erneuerbare Energien: Arbeitsplatzeffekte. Berlin, 2006.

[8] Institut für Zukunftsstudien und Technologiebewertung (IZT), Umweltbildung Erneuerbare Energien für Kinder und Jugendliche. WerkstattBericht Nr. 73, Berlin, 2005.

[9] Kammen, D., M.; Kapadia, K.; Fripp, M., Putting Renewables to Work. How Many Jobs Can the Clean Energy Industry Generate? Report of the Renewable and Appropriate Energy Laboratory (RAEL). University of California, Berkeley, 2004.

[10] Klimabündnis Österreich; Naturfreunde International; Institut für integrative Tourismus und Entwicklung. Fact Sheet Klimawandel und Tourismus - die Zusammenhänge. Wien, 2008.

[11] Koblmüller, M.; Bärntaler, J., Energie-Regionen: Worüber reden wir? Presentation on the conference: 'Energieregionen - Energie für Regionen'. Bruck/Leitha, 2009.

[12] Koch, R., Aichernig, C., Hofbauer, H., Rauscher, W., Fercher, E., Energieautarker Bezirk Güssing. Berichte aus der Energie- und Umweltforschung 82. Austrian Federal Ministry for Transport, Innovation and Technology. Wien, 2006.

[13] Kolomaznik, G., Gewitztes Burgenland: Energieautark bis 2015. VCÖ Mobilität mit Zukunft. Vol. 2006-5. Wien, 2006.

[14] Michalena, Using Renewable Energy as a Tool to Achieve Tourism Sustainability in Mediterranean Islands. Études cribéennes 11/2008.

[15] Müller, H., Scheurer, R. Angebots-Inszenierungen in Tourismusdestinationen. Jahrbuch der Schweiz. Tourismus-Wirtschaft (IDT). Bern, 2004.

[16] Novelli, M., Niche tourism: Contemporary issues, trends and cases. Burlington, 2005.

[17] Opaschovski, H., W., Kathedralen des 21. Jahrhunderts. Hamburg, 1998.

[18] Robinson, M. Novelli, M. Niche tourism: an introduction. In: Novelli 2005: Niche tourism: Contemporary issues, trends and cases. Burlington, 2005.

[19] Schulze, G., Die Erlebnisgesellschaft. 1993, 4. Auflage. Müller, Scheurer (Eds.), Angebots-Inszenierungen in Tourismusdestinationen. Jahrbuch der Schweiz. Tourismus-Wirtschaft (IDT). Bern, 2004.

[20] Skilift Lech, Umwelterklärung 2008. Lech, 2008.

[21] Smeral, E., Tourismusstrategische Ausrichtung 2015. Alpbach, 2007.

[22] TIS innovation park, Energie- und Umwelttourismus in Südtirol. Bozen, 2007.

[23] Zotz, A., Ökoenergie-Tourismus in Güssing. Integra 1, pp. 18-19. Wien, 2008 